\title{
The nature and objectives of anti-crisis financial management Sizova T. ${ }^{1}$, Sizova D. ${ }^{2}$ \\ Сущность и задачи антикризисного финансового управления Сизова Т. В. ${ }^{1}$, Сизова Д. А. ${ }^{2}$
}

\author{
${ }^{1}$ Сизова Татьяна Владимировна / Sizova Tatiana - кандидат экономических наук, доцент, \\ кафедра финансового менеджмента; \\ ${ }^{2}$ Сизова Дарина Александровна / Sizova Darina - кандидат экономических наук, дочент, \\ базовая кафедра экономического анализа и корпоративного управления производством и экспортом \\ высокотехнологичной продукиии Госкорпораиии «Ростех», \\ Федеральное государственное бюджетное образовательное учреждение высшего образования \\ Российский экономический университет имени Г. В. Плеханова, г. Москва
}

\begin{abstract}
Аннотация: данная публикащия посвящена рассмотрению сущности кризиса и антикризисного финансового управления. В данной статье авторами были определены цель и задачи антикризисного финансового управления, проведен анализ судебной практики по банкротствам за 2008-2015 годы, выявлены основные проблемы, исходя из которых определена значимость и роль принятия правильных финансовых управленческих решений как на высшем, так и низщем уровнях управления организацией.

Abstract: this article is devoted to consideration of the nature of crisis and anti-crisis financial management. In this article, the authors determined the purpose and tasks of anti-crisis financial management, the analysis of judicial practice in bankruptcy for the year 2008-2015, the main problems on which is defined the significance and role of management making the right financial decisions both at higher and lower levels of management organization.
\end{abstract}

Ключевые слова: антикризисное финансовое управление, банкротство, риски, кризис.

Keywords: anti-crisis financial management, bankruptcy, risk, crisis.

Сущность антикризисного финансового управления заключается в снижении вероятности возникновения кризиса и воздействии на ход его развития с целью минимизации негативных финансовых последствий для организации. Отсюда вытекают и задачи антикризисного финансового управления.

Первая - снижение вероятности возникновения финансового кризиса. Вторая - минимизация негативных финансовых последствий кризиса для организации.

Отметим, что каждая из вышепредставленных задач решается применением комплекса управленческих решений и контролем за их исполнением. При этом в антикризисной системе задействуются управленцы всех уровней и квалификаций, а не только, так называемое, «верхнее звено». К примеру, завхоз должен следить за исправностью электропроводки, наличием средств пожаротушения и прочее, юрист - за правильностью оформления документов на собственность, заключаемых договоров и т.п., бухгалтер - за процентными и депозитными ставками, налоговыми и акцизными изменениями и другими переменами в законодательстве, менеджер по продажам - за конъюнктурой товаров на рынке и действиями конкурентов. Таким образом, как мы видим, первая задача решается на низшем уровне управления. Для ее грамотного решения должны быть разработаны должностные инструкции с четким изложением служебных задач для всего персонала, и организована система отчетности и контроля за их исполнением. Вторым методом решения задачи является страхование рисков. Риски потому так и называются, поскольку могут быть рассчитаны вероятностными математическими методами на основе имеющейся статистики. В современной практике возможны различные виды страховок, таких как страхование урожая, груза, имущества и прочего. Однако страхование рисков ведет к уменьшению прибыли организации, и каждый управленец высшего звена решает сам - идти ли ему на этот риск, потеряв многое с малой долей вероятности, или потерять лишь часть прибыли. Как правило, большинство компаний принимают данное решение, полагаясь на «авось». В то же время, грамотное применение совокупности данных методов оказывает решающее влияние на недопущение возникновения финансового кризиса.

Однако отметим, что в условиях современной неопределенности, существующей в рыночной экономике, даже при идеальном выполнении служащими своих обязанностей существует вероятность возникновения финансового кризиса, и на первый план здесь выходит вторая задача. Она решается уже принятием решений на высшем уровне управления, для которых необходим анализ некоторых исходных данных. При этом, чем раньше будут приняты грамотные управленческие решения, тем лучше будет решена вторая задача. Кризис в запущенном состоянии практически неизлечим, что подтверждается данными судебной статистики по банкротствам из таблицы 1 , построенной на основании справки о рассмотрении арбитражными судами Российской Федерации дел о несостоятельности (банкротстве) в 
2008 - 2012 гг. [1], сведений о рассмотрении арбитражными судами Российской Федерации дел о несостоятельности (банкротстве) в 2010 - 2013 гг. [2], отчетов о работе арбитражных судов Российской Федерации по рассмотрению дел о банкротстве в 2014 и 2015 годах [3, 4].

Таблица 1. Анализ судебной статистики по банкротствам

\begin{tabular}{|c|c|c|c|c|c|c|c|c|}
\hline Годы & $\mathbf{2 0 0 8}$ & $\mathbf{2 0 0 9}$ & $\mathbf{2 0 1 0}$ & $\mathbf{2 0 1 1}$ & $\mathbf{2 0 1 2}$ & $\mathbf{2 0 1 3}$ & $\mathbf{2 0 1 4}$ & $\mathbf{2 0 1 5}$ \\
\hline $\begin{array}{c}\text { Поступило заявлений о признании } \\
\text { должников несостоятельными } \\
\text { (банкротами) }\end{array}$ & 34367 & 39579 & 40243 & 33385 & 40864 & 31921 & 41966 & 50779 \\
\hline $\begin{array}{c}\text { из них: } \\
\text { принято к производству }\end{array}$ & 27032 & 35545 & 33270 & 27422 & 33226 & 27351 & 35583 & 41040 \\
\hline $\begin{array}{c}\text { Количество дел, по которым } \\
\text { проводилась процедура } \\
\text { финансового оздоровления }\end{array}$ & 48 & 53 & 91 & 94 & 92 & 67 & 22 & 36 \\
\hline $\begin{array}{c}\text { из них: } \\
\text { прекращено производство по делу } \\
\text { в связи с погашением } \\
\text { задолженности }\end{array}$ & 6 & 2 & 6 & 7 & 3 & 4 & 6 & 7 \\
\hline В процентах: & 8.3 & 3.8 & 6.6 & 7.4 & 3.2 & 6.0 & 27.0 & 19.0 \\
\hline $\begin{array}{c}\text { Количество дел, по которым } \\
\text { проводилась процедура внешнего } \\
\text { управления }\end{array}$ & 579 & 604 & 908 & 986 & 922 & 803 & 381 & 413 \\
\hline $\begin{array}{c}\text { из них: } \\
\text { прекращено производство по делу } \\
\text { в связи с восстановлением } \\
\text { платежеспособности }\end{array}$ & 40 & 11 & 14 & 13 & 25 & 15 & 18 & 14 \\
\hline В процентах & 7.0 & 1.8 & 1.5 & 1.3 & 2.5 & 1.9 & 4.7 & 3.4 \\
\hline
\end{tabular}

Данные таблицы позволяют сделать несколько выводов:

1. Поступление заявлений о признании должников несостоятельными (банкротами) в 2015 году увеличилось на 20\% по сравнению с лучшими предшествующими годами, а также возросло и число принятых дел к судебному производству;

2. Соотношение дел, по которым прекращено судебное производство в связи с погашением задолженности из числа тех несостоятельных должников, по которым проводилась процедура финансового оздоровления за последние 8 лет, составляет 10,2\%. При этом, количество судебных дел, по которым проводилась процедура финансового оздоровления за последние 2 года, сократилось в 2-4 раза, а эффективность выросла до 19-27\%. Следовательно, на эту процедуру стало гораздо труднее попасть, но помогает она только одному из четырех - пяти несостоятельных должников (банкротов).

3. Соотношение дел, по которым прекращено судебное производство в связи с восстановлением платежеспособности из числа тех банкротов, по которым проводилась процедура внешнего управления, за последние 8 лет составляет 3,0\%.

Таким образом, можно отметить, что антикризисное финансовое управление компанией заключается в маневрировании финансами с целью наиболее эффективной нейтрализации вызовов, возникающих за счет негативного изменения факторов (рисков), оказывающих влияние на возможность возникновения и развития финансового кризиса компании. При этом, как было ранее сказано, эти риски, по большей части, имеют не финансовую природу. Так и борьба с последствиями их реализации (принимаемыми управленческими решениями) не всегда явно носит финансовый характер. Однако последствия их принятия всегда сводятся к перераспределению финансов компании. Таким образом, любое управленческое решение осуществляется в интересах и за счет маневра финансами.

В качестве примера рассмотрим туристическую отрасль в 2015 году, когда были введены ограничения на поездки в Египет и Турцию. Это были наиболее прибыльные направления и многие компании сделали ориентацию только на них. Результат известен, поскольку у них отсутствовала свобода маневра финансами.

Компании, предлагающие большое количество туристических продуктов, тоже понесли финансовые потери, но выстояли, мгновенно перебросив свои высвобождаемые финансовые ресурсы на увеличение закупки по заранее отработанным схемам и каналам других туристических продуктов и сокращая внутренние расходы до оптимальных за счет сокращения части сотрудников. При этом клиентура обанкротившихся компаний перешла к уцелевшим.

Из этого примера могут быть сделаны два важных вывода для предприятий всех отраслей:

1) Чтобы уменьшить риски негативных финансовых явлений при возникновении кризиса, необходима такая диверсификация направлений деятельности, при которой возникший вызов влиял бы лишь на часть 
ассортимента предлагаемого компанией продукта, что в свою очередь, повышает финансовую устойчивость предприятия и создает возможность финансового маневра.

2) Поскольку факторы, вызывающие кризис, зачастую возникают не в отдельно взятой компании, а в целом в секторе, необходимо не только пассивно бороться с последствиями этих факторов, но и, по возможности, усугублять их для конкурентов, удерживая и поднимая финансовое состояние компании за их счет, а также отслеживая и отражая их аналогичные действия, направленные против компании.

Вторым примером может служить увеличение или снижение выпуска какого-либо конкретного вида продукции промышленного предприятия, разработка нового вида продукции и т.п. Такие явно нефинансовые решения, в конечном счете, сводятся к тривиальным финансовым маневрам, высвобождая финансы на одном направлении и наращивая их на другом, беря кредит, в случае необходимости.

\section{Лumepamypa}

1. Официальный сайт Федеральных арбитражных судов Российской Федерации (Справка о рассмотрении арбитражными судами Российской Федерации дел о несостоятельности (банкротстве) в 2008 - 2012 гг.). [Электронный ресурс]: Режим доступа: http://www.arbitr.ru/press-centr/news/totals/ (дата обращения: 10.10.2016).

2. Официальный сайт Федеральных арбитражных судов Российской Федерации (Сведения о рассмотрении арбитражными судами Российской Федерации дел о несостоятельности (банкротстве) в 2010 - 2013 гг.). [Электронный ресурс]: Режим доступа: http://www.arbitr.ru/press-centr/news/totals/ (дата обращения: 10.10.2016).

3. Официальный сайт судебного департамента при Верховном суде Российской Федерации (Отчет о работе арбитражных судов Российской Федерации по рассмотрению дел о банкротстве в 2014 году). [Электронный pecypc]: Режим доступа: http://www.cdep.ru/index.php?id=79/ (дата обращения: 10.10.2016).

4. Официальный сайт судебного департамента при Верховном суде Российской Федерации (Отчет о работе арбитражных судов Российской Федерации по рассмотрению дел о банкротстве в 2015 году). [Электронный pecypc]: Режим доступа: http://www.cdep.ru/index.php?id=79/ (дата обращения: 10.10.2016). 